\title{
PREDATION ON SCINAX FUSCOVARIUS (ANURA, HYLIDAE) BY SCOLOPENDRA SP. (CHILOPODA: SCHOLOPENDRIDAE) IN THE STATE OF TOCANTINS, CENTRAL BRAZIL. DEPREDACIÓN DE SCINAX FUSCOVARIUS (ANURA: HYLIDAE) POR SCOLOPENDRA SP. (CHILOPODA: SCHOLOPENDRIDAE) EN EL ESTADO DE TOCANTINS, BRASIL.
}

\author{
HenriQue Folly ${ }^{1,2}$, Rafaela ThaleR ${ }^{1}$, Guilherme Bard Adams ${ }^{3}$ AND Elvis Almeida Pereira ${ }^{1,4 *}$ \\ ${ }^{1}$ Mapinguari - Laboratório de Biogeografia e Sistemática de Anfibios e Repteis, Universidade Federal de Mato Grosso do Sul, 79002-970, Campo \\ Grande, MS, Brazil. \\ ${ }^{2}$ Programa de Pós-Graduação em Biologia Animal, Museu de Zoologia João Moojen, Universidade Federal de Viçosa, 36570-900, Viçosa, MG, Brazil. \\ ${ }^{3}$ Biota Soluções Ambientais Ltda, Rua Lindolfo Collor, 439, sala 301, Centro, CEP 93010-080, São Leopoldo, RS, Brazil. \\ ${ }^{4}$ Programa de Pós-graduação em Biologia Animal, Departamento de Biologia Animal, Universidade Federal Rural do Rio de Janeiro, 23890-0oo, \\ Seropédica, RJ, Brazil. \\ "Correspondent:elvisaps@hotmail.com
}

Abstract.- Some arthropods groups produce substantial mortality in some vertebrate populations and have complex ecological interspecific interactions with vertebrates. Amphibians are preyed by invertebrates at all life stages, however no invertebrate species is recognized as specialist predator of this group. This short communication reports the predation of anuran by a centipede.

Keywords.- Natural history, feeding, tree frog, Scolopendra.

Resumen.- Algunos grupos de artrópodos producen una mortalidad sustancial en algunas poblaciones de vertebrados y tienen complejas interacciones ecológicas interespecíficas con vertebrados. Los anfibios son depredados por invertebrados en todas las etapas de la vida. Sin embargo, ninguna especie de invertebrado es reconocida como depredadora especializada de este grupo. Esta breve comunicación informa sobre la depredación de la rana por un ciempiés.

Palabras clave.- Historia natural, alimentación, rana arborícola, Scolopendra.

Anurans have a key role in many food chains, acting as either important predators or significant prey, since they are prey for many organisms, such as invertebrates, fishes, other amphibians, reptiles, birds, and mammals (Toledo, 2003, Toledo et al., 2007) and link terrestrial and aquatic ecosystems (Wilbur, 1997; Duellman \& Trueb, 1994; Whiles et al., 2006).

Scinax fuscovarius is a small nocturnal hylid with a wide distribution, occurs in Brazil, northern Argentina, Paraguay, and Bolivia, 150-1800 m elevation (e.g., Arrieta \& Maneyro, 1999; Achaval \& Olmos, 2003; Eterovick \& Sazima, 2004; Baldo \& Rosset, 2006; Brusquetti \& Lavilla, 2006; Canelas \& Bertoluci,
2007; Cruz et al., 2009). In Brazil, it occurs in all biomes except the Amazon rainforest (e.g., Morais et al., 2011; Haddad et al., 2013), and in areas with high anthropogenic impact, such as open area and residences (Santana et al., 2013).

There are records of predation of this species by several vertebrates such as snakes (Bernarde et al., 2000; Kokubum \& Maciel, 2010; Silva et al., 2011), other anurans (Bezerra et al., 2015), lizards (Maffei et al., 2009); domestic cats (Oda et al., 2010) and birds (Morais et al., 2013); and also, invertebrates such as Odonata larvae (Fulan \& Almeida, 2010), water bugs and spiders (Maffei et al., 2014). 


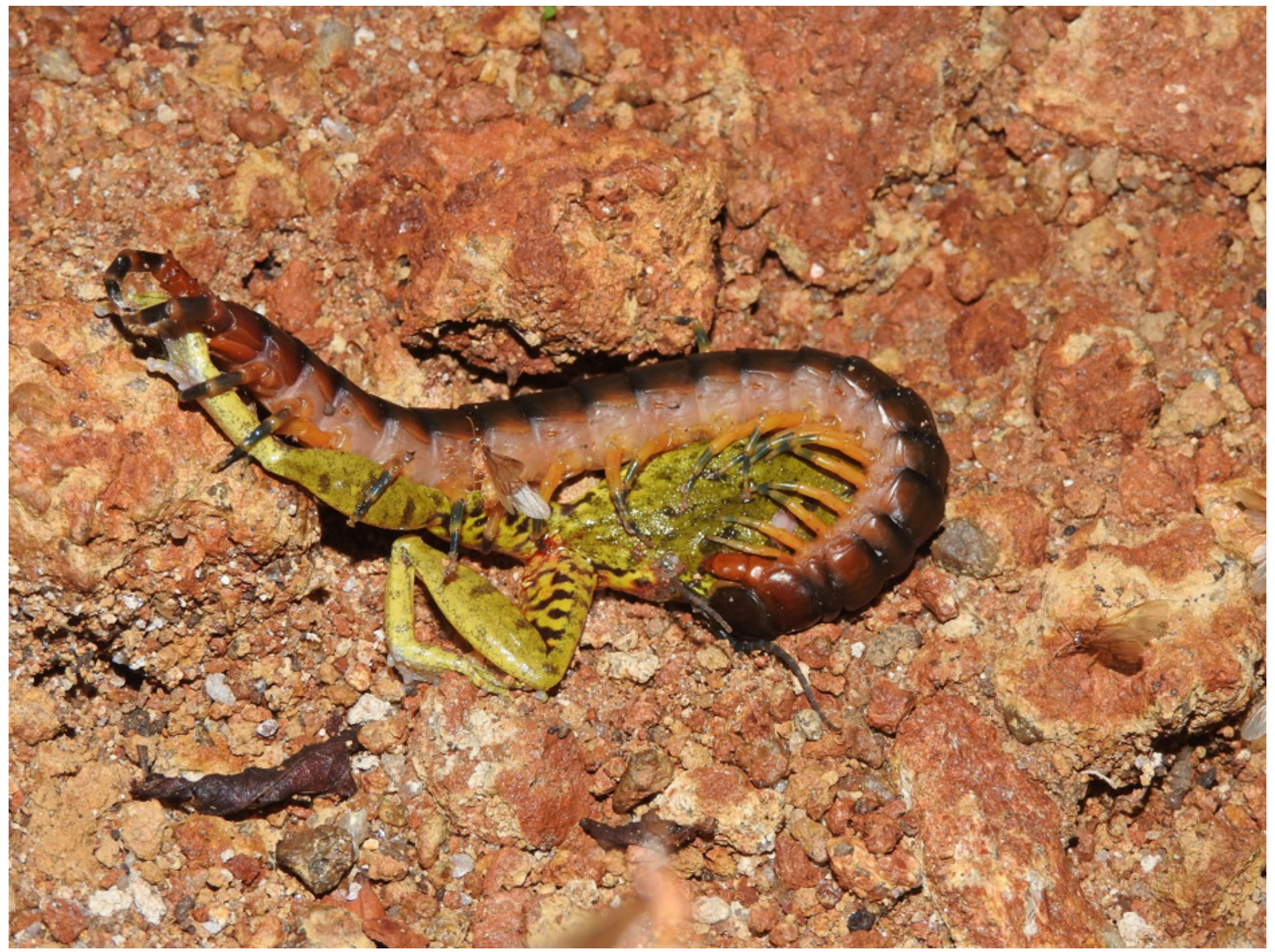

Figure 1. Predation of Scinax fuscovarius by Scolopendra sp., Municipality of Gurupi, State of Tocantins, Brazil. Photo by Guilherme Adams.

Figura 1. Deredation of Scinax fuscovarius por Scolopendra sp., Municipio de Gurupi, Estado de Tocantins, Brasil. Foto de Guilherme Adams.

Invertebrates are an important component of the food web, serving as prey for many vertebrate groups (McCormick \& Polis, 1982; Johnson et al., 2004; Menin et al., 2005; Figueiredo-deAndrade et al., 2010). However, some arthropods groups also produce substantial mortality in some vertebrate populations (McCormick \& Polis, 1982; Toledo et al., 2007) and have complex ecological interspecific interactions with vertebrates (Menin et al., 2005). Amphibians are preyed by invertebrates at all life stages, however no invertebrate species is recognized as specialist predator of this group. Most species are generalist predators that feed opportunistically on available food items (Wells, 2007).

The Chilopoda class is found on every continent except
Antarctica (Lewis, 1981; Edgecombe \& Giribet, 2007). They have nocturnal habits and prefer damp places, hiding during the day and feeding at night. They are terrestrial, opportunistic, voracious and strictly carnivorous, feeding mainly on insects (Ruppert \& Barnes, 1994; Hickman et al., 1997; Dugon \& Arthur, 2012a, b; Vijayakumar et al., 2012). Giant centipedes (Scolopendridae) belong to the few terrestrial arthropods can also attack small frogs, toads, lizards, snakes, birds, bats, mice, voles and other small rodents, particularly juveniles (Cloudsley-Thompson, 1955, 1958; Shugg, 1961; Porter, 1973; Lewis, 1981; Easterla, 1975; Clark, 1979; McCormick \& Polis, 1982; Carpenter \& Gillinham, 1984; Bush et al., 2001; Molinari et al., 2005; Mirza \& Ahmed, 2009; Charles \& Smith, 2009; Araújo et al., 2012; Jestrzemski \& Schutz, 2016; Chiacchio et al., 2017; Lindley et al., 2017). 
The record was observed on November 9, 2017 at approximately 22:0oh, it the Municipality of Gurupi, State of Tocantins. The predation by Scolopendra sp event occurred in a temporary pond (11. $47334444^{\circ} \mathrm{S}, 48.8144^{\circ} \mathrm{W}, 275 \mathrm{~m}$ a.s.l WGS 84 ) while the male of Scinax fuscovarius was vocalizing. During the reported event, other individuals of the same species were also vocalizing. The observation was recorded in video and photography and is maintained in the media files at the Coleção Zoológica da Universidade Federal de Mato Grosso do Sul. The treefrog species was collected and is housed in the Coleção Zoológica da Universidade Federal de Mato Grosso do Sul, Municipality of Campo Grande, Mato Grosso do Sul state, Brazil (ZUFMSAMP09776; Fig. 1). It was not possible to deposit the chilopodan in the collection, because it escaped soon after the recording.

Vertebrates may be particularly rewarding prey for centipedes because of their nutritional composition, and because the quantity of nutrients per individual prey exceeds that provided by invertebrates (Molinari et al., 2005). However, owing to their comparatively large body size, vertebrates could be dangerous prey for centipedes. Large centipedes do not necessarily avoid potentially combative prey, such as toads and snakes (Carpenter \& Gillingham, 1984; Mirza \& Ahmed, 2009). Predation on vertebrates is thought to be an occasional behavior among large scolopendrid centipedes.

Ours and previous reports imply that the choice of vertebrates as prey by large centipedes, though opportunistic, might be a relatively frequent behavior. This short communication improves the knowledge on the trophic interactions between arthropods and anurans in Brazil, reporting for the first time S. fuscovarius as a prey of a chilopodan.

Acknowledgements.- We thank the Instituto Chico Mendes de Conservação da Biodiversidade for collection permits, Biota Soluções Ambientais Ltda. for support during the fieldwork and EAP acknowledges support scholarship from Conselho Nacional de Desenvolvimento Científico e Tecnológico (CNPq).

\section{CITED LITERATURE}

Achaval, F. \& A. Olmos. 2003. Anfibios y Reptiles del Uruguay. Segunda edicion. Graphis, Montevideo.

Araujo, A.C.S., M.R. Nogueira, I.P. Lima \& A.L. Peracchi. 2012. Predation by the centipede Scolopendra viridicornis (Scolopendromorpha, Scolopendridae) on roof-roosting bats in the Atlantic Forest of southeastern Brazil. Chiroptera Neotropical 18: $1128-1131$.

Arrieta, D. \& R. Maneyro. 1999. Sobre la presencia de Scinax fuscovarius (A. Lutz, 1925) (Anura, Hylidae) en Uruguay. Boletín de la Sociedad Zoológica del Uruguay 2: 15-19.

Baldo, D. \& S.D. Rosset. 2006. Geographic distribution: Scinax fuscovarius. Herpetological Review 37: 103-104.

Bernarde, P.S., J.C. Moura-Leite, R.A. Machado \& M.N.C. Kokobum. 2000. Diet of the colubrid snake, Thamnodynastes strigatus (Günther, 1858) from Paraná state, Brazil, with field notes on anuran predation. Revista Brasileira de Biologia 60: 695-699.

Bezerra, A., J. Ruggeri \& S.P. Carvalho-e-Silva. 2015. Scinax fuscovarius (Snouted Treefrog). Predation. Herpetological Review 46: 239

Brusquetti, F. \& E.O. Lavilla. 2006. Lista comentada de los anfibios de Paraguay. Cuadernos de Herpetología, Buenos Aires 20: 3-79.

Bush, S.P., B.O. King, R.L. Norris \& S.A .Stockwell. 2001. Centipede envenomation. Wilderness \& Environmental Medicine 12: 93-99.

Canelas, M.A.S. \& J. Bertoluci. 2007. Anurans of the Serra do Caraça, southeastern Brazil: species composition \& phenological patterns of calling activity. Iheringia. Série Zoologia, Porto Alegre 97: 21-26.

Carpenter, C.C. \& J.C. Gillinham. 1984. Giant centipede (Scolopendra alternans) attacks marine toad (Bufo marinus). Caribbean Journal of Science 20: 71-72.

Charles, S.P. \& S. Smith. 2009. Gonatodes vittatus as Prey of Hemidactylus palaichthus and Potential Prey of Scolopendra gigantea. Living World, Journal of the Trinidad and Tobago Field Naturalists' Club, Caribbean Basin 42-43.

Chiacchio, M., B.S. Nadolski, P. Suwanwaree \& S. Waengsothorn. 2017. Centipede, Scolopendra dawydoffi (Chilopoda: Scolopendridae), predation on an egg-laying snake, Sibynophis triangularis (Squamata: Colubridae), in Thailand. Journal of Insect Behavior 30: 563-566.

Clark, DB. 1979. A centipede preying on a nesting rice rat (Oryzomys bauri). Journal of Mammalogy, Oxford 60: 654.

Cloudsley-Thompson, J.L. 1955. Some aspects of the biology of 
centipedes and scorpions. Naturalist 6:147-153.

Cloudsley-Thompson, J.L. 1958. Spiders, scorpions, centipedes and mites. Pergamon Press, New York, EUA.

Cruz, CAG, R.N. Feio, U. Caramaschi \& R. Murta. 2009. Anfíbios do Ibitipoca. Bicho do Mato Editora, Belo Horizonte, Brazil.

Duellman, W.E. \& L. Trueb. 1994. Biology of amphibians, 2nd edition. Baltimore, Johns Hopkins University Press.

Dugon, M.M. \& W. Arthur. 2012a. Comparative studies on the structure and development of the venom-delivery system of centipedes, and a hypothesis on the origin of this evolutionary novelty. Evolution e Development, Medford 14: 128-137.

Dugon, M.M. \& W. Arthur. 2012b. Prey orientation and the role of venom availability in the predatory behavior of the centipede Scolopendra subspinipes mutilans (Arthropoda: Chilopoda). Journal of Insect Physiology 58: 874-880.

Easterla, D.A. 1975. Giant desert centipede preys upon snake. The Southwestern Naturalist 20: 411.

Edgecombe, G.D. \& G. Giribet. 2007. Evolutionary biology of centipedes (Myriapoda: Chilopoda). Annual Review of Entomology 52: 151 .

Eterovick, P.C. \& I. Sazima. 2004. Anfibios da Serra do Cipó. Editora PUC Minas. Minas Gerais, Brazil.

Figueiredo-de-Andrade, C.A., D.J. Santana \& S.P. Carvalho-e-Silva. 2010. Predation on Scinax $x$-signatus (Anura: Hylidae) by the giant water bug Lethocerus annulipes (Hemiptera: Belostomatidae) in a Brazilian Restinga habitat. Herpetology Notes 3: 53-54.

Fulan, J.Â. \& S.C. Almeida. 2010. Effect of the spatial heterogeneity on the predation of Scinax fuscovarius and Physalaemus cuvieri tadpoles by Odonata larvae. Acta Scientiarum. Biological Sciences 32: 121-124.

Haddad, C.F.B., L.F .Toledo, C.P.A. Prado, D. Loebmann, J.L. Gasparini \& I. Sazima. 2013. Guia dos anfíbios da Mata Atlântica: diversidade de biologia. Anolisbooks. São Paulo, Brasil.

Hickman, C, L. Roberts \& A. Larson. 1997. Integrated Principles of Zoology. Brown Publishers, New York, EUA.

Jestrzemski, D. \& S. Schütz. 2016. Arthropods as predators of herpetofauna in Chu Mom Ray National Park, Vietnam. Asian Journal of Conservation Biology 5: 3-15.

Johnson, N.F., C.A. Triplehorn \& Borror, DJ. 2004. Introduction to the study of insects. Thompson Brooks Cole, Belmont, California, EUA.

Kokubum, M.N.C. \& N.M. Maciel. 2010. Scinax fuscovarius: Predation. Herpetological Review 41: 480-481.

Lewis, J.G.E. 1981. The Biology of Centipedes. Cambridge University Press. Cambridge, England.

Lindley, T.T., J. Molinari, R.M. Shelley \& B.N. Steger. 2017. A fourth account of centipede (Chilopoda) predation on bats. Insecta Mundi 573: 1-4.

Maffei, F., M. Bolfarini \& F.K. Ubaid. 2014. Predation of Scinax fuscovarius (Anura: Hylidae) by two invertebrates in Southeastern Brazil. Herpetology Notes 7: 371-374.

Maffei, F., F.K. Ubaid, C.A.B. Medolago \& J. Jim. 2009. Tupinambis merianae (Common Tegu) Diet. Herpetological Review 40: 439.

McCormick, S. \& G.A. Polis. 1982. Arthropods that prey on vertebrates. Biological Review 57: 29-58.

Menin, M., D.J. Rodrigues \& C.S. Azevedo. 2005. Predation on amphibians by spiders (Arachnida, Araneae) in the neotropical region. Phyllomedusa 4: 39-47.

Mirza, Z.A. \& J.J. Ahmed. 2009. Note on predation of Calliophis melanurus Shaw, 1802 (Serpents: Elapidae) by Scolopendra sp.. Hamadryad 34: 166.

Molinari, J., E.E. Gutiérrez, A.A. Ascenção, J.M. Nassar, A. Arends \& R.J. Márquez. 2005. Predation by giant centipedes, Scolopendra gigantea, on three species of bats in a venezuelan cave. Caribbean Journal of Science 41:340-346.

Morais, A.R., M.N. Siqueira \& R.P. Bastos. 2013. Predation on a Neotropical treefrog (Scinax aff. fuscovarius) by Guira guira (Aves, Cuculidae) in the state of Goiás, Central Brazil. Herpetology Notes 6:567-568.

Morais, A.R., L. Signorelli, P.G. Gambale, K. Kopp, F. Nomura, L.D .Guimarães, W. Vaz-Silva, J. Ramos \& R.P. Bastos. 2011. Anfíbios anuros associados a corpos d'água do sudoeste do estado de Goiás, Brasil.- Biota Neotropica 11: 355-363. 
Oda, F.H., T.M. Oda, V.A. Campos \& M.A.C.S. Lima. 2010. Scinax fuscovarius (Snouted Treefrog). Predation. Herpetological Review 41: 481.

Porter, R.N. 1973. Centipede feeding on field mouse. Lammergeyer 19:31.

Ruppert, E. \& R. Barnes. 1994. Invertebrate Zoology. Saunders College Publishing. New York, USA.

Santana, D.J., V.A. São Pedro, P.S. Hote, H.M. Roberti, A.C. Sant'Anna, C.A. Figueiredo-de-Andrade \& R.N. Feio. 2013. Anurans in the regions of the High Muriae River, State of Minas Gerais, Brazil. Herpetology Notes 3: 1-10.

Shugg, H.B. 1961. Predation on mouse by centipede. Western Australian Naturalist 8: 52.

Silva, R.A., F.H. Oda, M.F. Felismino, V.A. Campos \& T.M. Oda. 2011. Bothrops moojeni (Brazilian Lancehead). Diet. Herpetological Review 42: 283-284.

Toledo, L.F., R.S. Ribeiro \& C.F.B. Haddad. 2007. Anurans as prey: an exploratory analysis and size relationships between predators and their prey. Journal of Zoology 271: 170-177.
Toledo, L.F. 2003. Predation on seven South American anuran species by water bugs (Belostomatidae). Phyllomedusa 2: 105108.

Vijayakumar, K. \& M. Muthuraman, R. Jayaraj. 2012. Predation of stingless bees (Trigona iridipennis: Apidae, Meliponinae) by centipede (Scolopendra hardwicki: Chilopoda: Scolopendramorpha). International Journal of Advanced Life Sciences 5: 156-159.

Wells, K.D. 2007. The ecology and behavior of amphibians. The University of Chicago, London.

Whiles, M.R., K.R. Lips, C.M. Pringle, S.S. Kilham, R.J. Bixby, R. Brenes, S. Connelly, J.C. Colon-Gaud, M. Huntebrown, A.D. Huryn, Y.C. Montgomer \& S. Peterson. 2006. The effects of amphibian population decline on the structure and function of Neotropical stream ecosystems. Frontiers in Ecology and the Environment 4:27-34.

Wilbur, H.M. 1997. Experimental ecology of food webs: Complex systems in temporary ponds. Ecology 78: 2279-2302.

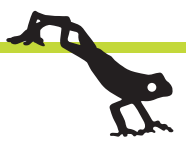

